\title{
FLORISTIC COMPOSITION AND PLANT COMMUNITY TYPES IN MAZE NATIONAL PARK, SOUTHWEST ETHIOPIA
}

\author{
SIRAJ, M. ${ }^{1,3}-$ ZHANG, $\mathrm{K}^{*}{ }^{*}-$ SEBSEBE, D. $^{2}-$ ZERIHUN, ${ }^{2}{ }^{2}$ \\ ${ }^{1}$ Beijing Forestry University, School of Soil and Water Conservation \\ Beijing 100083, China \\ ${ }^{2}$ Addis Ababa University, Department of Plant Biology and Biodiversity Management \\ Addis Ababa, Ethiopia \\ ${ }^{3}$ Ambo University, Department of Biology \\ Ambo, Ethiopia \\ *Corresponding author \\ e-mail: ctccd@126.com; phone: +86-10-62338158.
}

(Received $2^{\text {nd }}$ Mar 2016; accepted $16^{\text {th }}$ Jun 2016)

\begin{abstract}
Ethiopia has established protected areas throughout the country and designated many areas of land in order to conserve the natural resources and biodiversity. Hence, identification of the diversity in these protected areas is essential for conservation and management purposes. The study was conducted with the objective to investigate and document the floristic composition and plant community types of Maze national park. A preferential sampling technique was used as a sampling design and a total of 65 plots with a size of $20 \mathrm{~m} \times 20 \mathrm{~m}\left(400 \mathrm{~m}^{2}\right)$ were laid out for the woody species; a sub-plot of $5 \mathrm{~m}$ x $5 \mathrm{~m}$ was used at the center of each quadrat to assess the herbaceous species. A total of 144 species of vascular plants belonging to 109 genera and representing 37 families with, 40\%, 37\%, 17\%, and $6 \%$ herbs, trees, shrubs and climbers respectively were recorded and identified. The most diverse family was Fabaceae followed by Poaceae, Euphorbiaceae, and Asteraceae. Combretum adenogonium, Rhus natalensis, Panicum maximum, are the most frequently occurring tree layer, shrub layer and herb layer plant species respectively. The output of TWINSPAN (Two-Way Indicator Species Analysis) has shown a cluster of 6 plant community types. The Analysis of Variance (ANOVA) has shown that there was statistically significant difference among plant communities in species richness, altitude, diversity and evenness at $95 \%$ confidence interval with a $\mathrm{P}$ value $<0.05$. Anthropogenic activities in Maze National Park were identified to exert high pressure on the vegetation and wildlife in the area resulting in the loss of biodiversity underpinned by troubled natural habitat. The most feasible recommendation to reverse the undesirable condition in the national park is to actively participate the local people in the conservation activities of the national park via ecotourism which is one form of sustainable tourism.
\end{abstract}

Keywords: biodiversity, Ethiopia, Maze National Parks, plant diversity; protected areas

\section{Introduction}

Ethiopia is a country located in the Horn of Africa and has great topographical diversity with flat-topped plateaus, high mountains, river valleys, deep gorges, rolling plains, and with great variation of altitude from 116 meters below sea level, in some areas of Kobar Sink to 4620 meters above sea level at Ras Dashen (IBC, 2012). These diverse physiographic features have contributed to the formation of different ecosystems characterized by variations in biodiversity. The country is endowed with rich diversity of flora and fauna as well as rich in endemic species. The flora of Ethiopia encompasses about 6,027 vascular plant species with $10 \%$ endemic (Kelbessa and Demissew, 2014); this distribution puts the country in the fifth largest floral composition in tropical Africa (Didita et al., 2010). The fauna 
includes 860 avian species 16 of which are endemic and two genera are endemic too; Mammals 279 species, of which 35 are endemic and six genera are endemic too. The country is also home of a number of charismatic and endemic flagship species. The protected areas such as national parks, sanctuaries, controlled hunting, open hunting, wildlife reserves and community conservation areas coverage share only about $15 \%$ of the total land area of the country (BIDNTF, 2010; Chanie and Tesfaye, 2015). The rich biodiversity of the country is under serious threat from deforestation and land degradation, overexploitation, overgrazing, habitat loss, invasive species and some water pollution (IBC, 2009).

IUCN defines a protected area as an area of land and/or sea especially dedicated to the protection and maintenance of biological diversity, and of natural and associated cultural resources, and managed through legal or other effective means. Protected areas represent a defined and delimited geographical space which aims at the conservation of nature with associated ecosystem services and cultural values (Dudley, 2008). Protected areas play a key role in safeguarding biodiversity and sustaining the crucial services provided by the ecosystems (Chanie and Tesfaye, 2015). Protected areas are playing an important role in scientific research; wilderness protection; preservation of species and genetic diversity; maintenance of environmental services; protection of specific natural and cultural features; tourism and recreation; education; sustainable use of resources from natural ecosystems; maintenance of cultural and traditional attributes (Ahmet and Meric, 2000). National parks are the most extensive type of protected areas in Africa and globally (Muhumuza and Balkwill, 2013). National parks are important in biodiversity conservation and maintaining natural ecosystems functioning, as refuges for species and maintaining ecological processes. However, many of these biological sanctuaries are currently affected by a series of social, political, industrial, and institutional challenges (Khadka, 2010).

The primary mechanism used by Ethiopia to protect biodiversity, ecosystems and ecological processes has been through a network of wildlife conservation areas and priority forest areas (FDRE, 2007). Ethiopia has established protected areas throughout the country and designated many protected areas of land as national parks, wildlife ranches, wildlife sanctuaries, wildlife reserves, and biosphere reserves and national forest priority areas for biodiversity, wildlife and forest conservation (Kelboro and Stellmacher, 2012). Protected areas play an important role in the sustainable development of national economy by providing environmental services such as offering ecotourism and safari experiences to the recently blooming tourism sector (Vreugdenhil et al., 2011). National parks are among widely used means of nature conservation in Ethiopia (Stellmacher, 2007). National parks enable a country to protect biodiversity in its representative ecosystems within their natural habitats (Kelboro and Stellmacher, 2012). Ethiopian national parks are characterized by exclusive conservation approaches, and this may not be effective because of conflicts between local people living in or around the parks and state authorities (Debelo, 2012; Kelboro and Stellmacher, 2012; Stellmacher and Nolten, 2010), leading to the loss of biodiversity. Ethiopian protected areas face significant challenges in meeting the needs local community and state conservation dilemma. The loss of forest cover and biodiversity due to human-induced activities is a growing concern in many parts of the world (Senbeta and Teketay, 2003) and protecting these areas is important to curb the loss of 
habitat and biodiversity. The major threats to the biodiversity of the country are over-harvesting, deforestation, conversion of natural vegetation to farmland, forest fires, land degradation, habitat loss and fragmentation, invasive species, illegal trafficking of domestic and wild animals, poaching, wetland destruction and climate change (IBC, 2009) whereas protected areas frequently serve to insulate biodiversity from the impacts of human development (Rai and Sundriyal, 1997; Shackleton, 2000)

In order to sustain the ecological equilibrium of the environment and meet the forest resource requirements of the population, collection of scientific information on the composition, structure and distribution of the species becomes a primary activity in areas where it has not been achieved (Ayalew et al., 2006). Maze National Park is one of the national parks in Ethiopia where such study has not been conducted before on plant species diversity, distribution patterns and plant community composition. Systematic field survey of flora and fauna is a prerequisite for developing effective conservation programs and its implementation. These collected information on vegetation may be required to solve an ecological problem, for biological conservation and management purposes; as an input to environmental impact statements; to monitor management practices or to provide the basis for prediction of possible future changes (Kent and Coker, 1992). Hence, identification of the diversity in these areas is essential for conservation and management purposes.

The role of protected areas in conserving natural resources is well established; while, the role of humans in these areas continues to be debated (Katherine, 2013). Conventional protected areas approaches have tended to see people and nature as separate entities, often requiring the exclusion of human communities from areas of interest, prohibiting their use of natural resources and seeing their concerns as incompatible with conservation, this exclusionary approaches have engendered profound social costs (IUCN, 2004). This further caused an illegal and unsustainable natural resource utilization (Siraj et al, 2016). The importance of protected areas and their nexus to environment and development issues has got worldwide recognition and reflected on different international conference such as, the UN Conference on Environment and Development in 1992 and other international and regional environmental agreements (Chape et al., 2003). In Ethiopia the importance of biodiversity conservation and benefits of ecosystem services are not well-understood by a large number of people at all levels, particularly by policy makers (IBC, 2009). Understanding plant species distribution patterns and plant community composition along environmental gradients gives key information for effective management of forest ecosystems (Lovett et al., 2000; Noss, 1999; Naveh and Whittaker, 1980). Thus, it is important to identify plant species diversity and community composition along environmental gradients. Hence, the objectives of this study was to investigate and document the floristic composition of the Maze National Park, to classify the vegetation of Maze National Park into plant community types, and to assess the status of the vegetation and to make some recommendations on the management and conservation of the park. 


\section{Materials and Methods}

\section{Study area description}

The study was conducted in Maze National Park at Gamo Gofa Zone, Southern Nations, Nationalities and Peoples' Regional State (SNNPRS), southwest Ethiopia as shown (Fig. 1). The park is surrounded by five districts namely Qucha on the northern part, Gofa on the northwest, Deramalo on the south and southeast, Zala on the southwest, and Kemba on south. The study area Maze National Park lies between $\left(06^{\circ}\right.$ $3^{\prime}$ to $06030^{\prime} \mathrm{N}$ latitude and $37^{\circ} 25^{\prime}$ to $037^{\circ} 40^{\prime} \mathrm{E}$ longitude (Refera and Bekele, 2006) and altitude ranges from $900 \mathrm{~m}$ to $1200 \mathrm{~m}$ above sea level. The park is located $460 \mathrm{~km}$ and south west of Addis Ababa in Gamo-Gofa Zone on the road to Sawula city. Maze National Park was established in 2005 and serves as one of the last remaining sites for the conservation of the Swayne's Hartebeest second to Senkelle Hartebeest Sanctuary (Tekalign and Bekele, 2011). The park is mainly in Combretum-Terminalia woodland type of vegetation and covers an area of $204 \mathrm{Km}^{2}$ and lies near the middle of Omo river valley. Maze National Park was named after the Maze river which rises from southern parts of the surrounding highland and passes through the park from south to north direction and eventually drain in to Omo river.

Maze National Park is one of the national parks designated for wildlife conservation and known for its good population of the critically endangered endemic Swayne's Hartebeests population in Ethiopia. Maze National Park is an important biological area and has great potential for the conservation of the endangered endemic subspecies of Swayne's hartebeest population and other wildlife (Refera and Bekele, 2006).

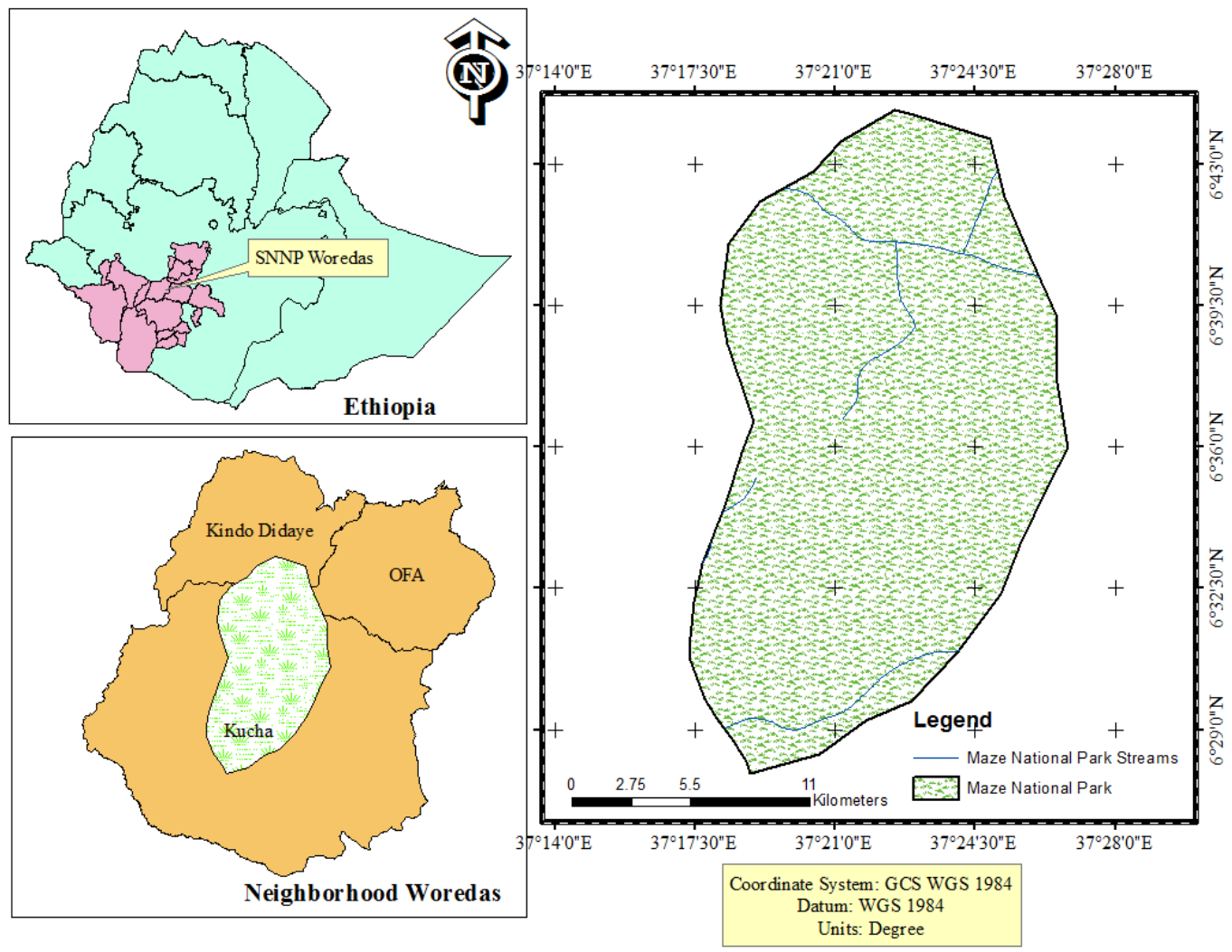

Figure 1. Location Map of the Maze National Park 


\section{Sampling design}

Following a reconnaissance survey, actual sampling of vegetation was done between November 8 and December 5, 2007 focusing on homogeneity via preferential means in some parts of the park (Tela Ayisera, Molisha, Maze river and Lemase river) areas. The data collection was done following the methodology used in studying the vegetation of Ethiopia by (Ayalew et al., 2006; Demissew, 1980; Andargie, 2001; Bekele, 1994; Woldu, 1985). A preferential sampling technique was used as a sampling design and a total of 65 plots with a size of $20 \mathrm{~m}$ x $20 \mathrm{~m}\left(400 \mathrm{~m}^{2}\right)$ were laid out for the woody species; a sub-plot of $5 \mathrm{~m} \times 5 \mathrm{~m}$ was used at the center of each quadrat to assess the herbaceous species. All the vascular plant species in the plots were recorded and their cover abundance in each plots was estimated and rated according to modified Braun Blanquet approach (Van der Maarel, 1979). The collected plant specimens were pressed properly and were brought to the National Herbarium (ETH), Addis Ababa University for identification. The specimens were dried and identified by using authenticated specimens, consulting experts and referring to the Flora of Ethiopia and Eritrea.

\section{Climate}

The rainfall and temperature data for 9 years between1997-2005 was taken from Ethiopian National Meteorological Agency (ENMA) which is recorded at Morka Peasant Association situated near Maze National Park, that lies almost at the same altitudes. Based on the 9 years rainfall summarized data, the rainfall in the study area is bimodal (having two rain seasons). The total amount of annual rainfall in the area varies between 2841.6 and $3299.8 \mathrm{~mm}$. The longest rainy season in the area extends from April up to October month in which high amount of rainfall is recorded between April and June (Fig. 2).

There is no consecutive and regularly recorded temperature data of the area; instead a summarized temperature data of the area was taken. The hottest months of the area include December, January, February and March with mean maximum temperature $32.88^{\circ} \mathrm{C}$. The cooler months in the area include June, July and August with mean minimum temperature of $17.5^{\circ} \mathrm{C}$ (Fig. 2).

\section{Data analysis}

\section{Plant community}

A plant community is characterized by its essential homogenous physiognomy and ecological structure and by its floristic composition, at least with regard to dominance (Tothill, 1978). The description of plant community involves the analyses of species diversity, evenness and similarity (Whittaker, 1975). All vascular plant species present in sampling unit were recorded and percentage aerial cover/abundance of each species was estimated based on 1-9 scale of Braun-Blanquet (as modified by Van der Maarel, 1979): $1=$ rare generally only one individual; $2=$ sporadic (few) which are less than $5 \%$ cover of the total area; $3=$ abundant with less than $5 \%$ cover of the total area; $4=$ very abundant and less than 5\% cover of the total area; $5=5-12 \%$ cover of the total area; $6=$ $12.5-25 \%$ cover of the total area; $7=25-50 \%$ cover of the total area; $8=50-75 \%$ cover of the total area; $9=75-100 \%$ cover of the total area. TWINSPAN was used to classify plant communities in the study area and MINITAB 14 computer program was used to 
analyses the variation among the communities in species richness, altitude, evenness and species diversity.

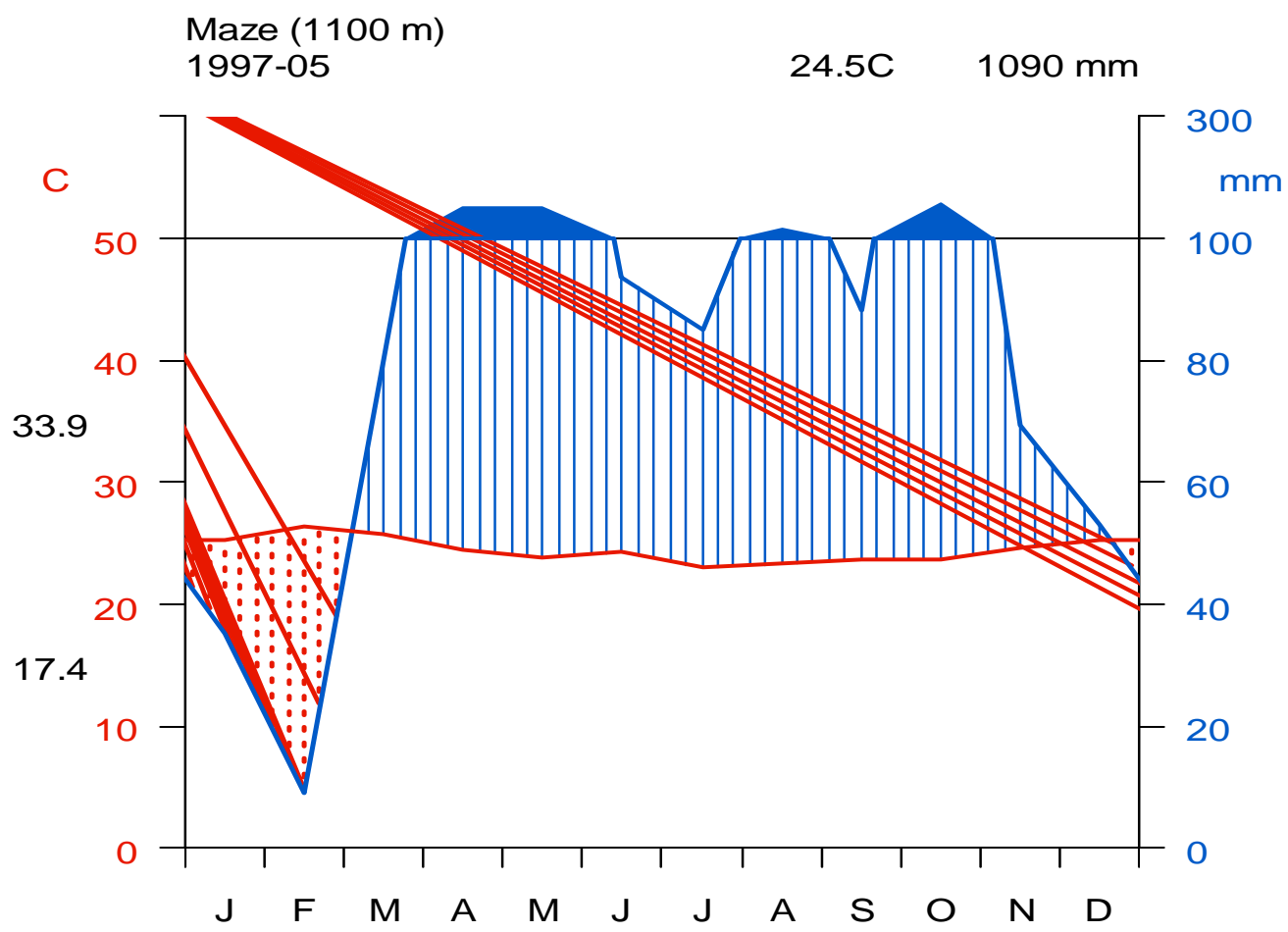

Figure 2. Average maximum, minimum temperature and average rainfall, Source: - ENMA (2007)

\section{Plant diversity analysis}

The evenness and diversity of plant species was analyzed using the Shannon Evenness Index (E) and Shannon-Wiener Diversity Index (H) (Jayarman, 2000). Shannon and Wiener (1949) index of species diversity was applied to quantify species diversity and richness. This method is one of the most widely used approaches in measuring the diversity of species. The diversity of each cluster was calculated using Shannon-Weiner diversity index, based on cover/abundance value of the species as input source. The relative equitability (evenness) of the species in each cluster was also calculated.

\section{Frequency}

Frequency is the number of times a species occurs in a given number of repeatedly placed small sample plots or sample points. The frequencies of the vascular plant species in all the 65 plots were computed. The higher the frequency, the more important the plant is in the community. The importance of a species with frequency was obtained by comparing the frequency of occurrences of all of the plant species present. Relative frequency was calculated for the most frequent tree species in the study area following Martin (1995) and Jha (1997) (Eq. 1 and 2). 


$$
\text { Re lativeFrequency }=\frac{\text { Frequency.of } . \text { a.species } \times 100}{\text { Total.frequency.of.all.species }}
$$

Frequency $\%=\frac{\text { Number.of.plots.with.individual } . \text { species } \times 100}{\text { Total.number.of.plots.studied }}$
(Eq.1)

\section{Results and Discussion}

\section{Floristic composition and diversity}

The analysis of floristic data on Maze National Park vegetation occurring between altitudinal gradients of $937 \mathrm{~m}$ and $1076 \mathrm{~m}$ a.s.l. indicates the presence of higher species diversity. A total of 144 species (a complete species list can be provided upon request) belonging to 109 genera and 37 families were recorded. The most species-diverse families are Fabaceae/Leguminosae represented by 29 species $(20.14 \%)$ followed by, Poaceae 23 species (15.97\%), Euphorbiaceae 9 (6.25) species; Asteraceae 7 (4.86) species; Lamiaceae 6 (4.17) species; Acanthaceae, Combretaceae and Anacardiaceae each by 5 (3.47) species as shown in Figure 3. These 8 families constituted $61.8 \%$ of the species in the study area while the rest of the families contributes $38.2 \%$. Out of the identified species, $40 \%$ were herbs, $37 \%$ trees, $17 \%$ shrubs, and $6 \%$ were climbers (Fig. 4).

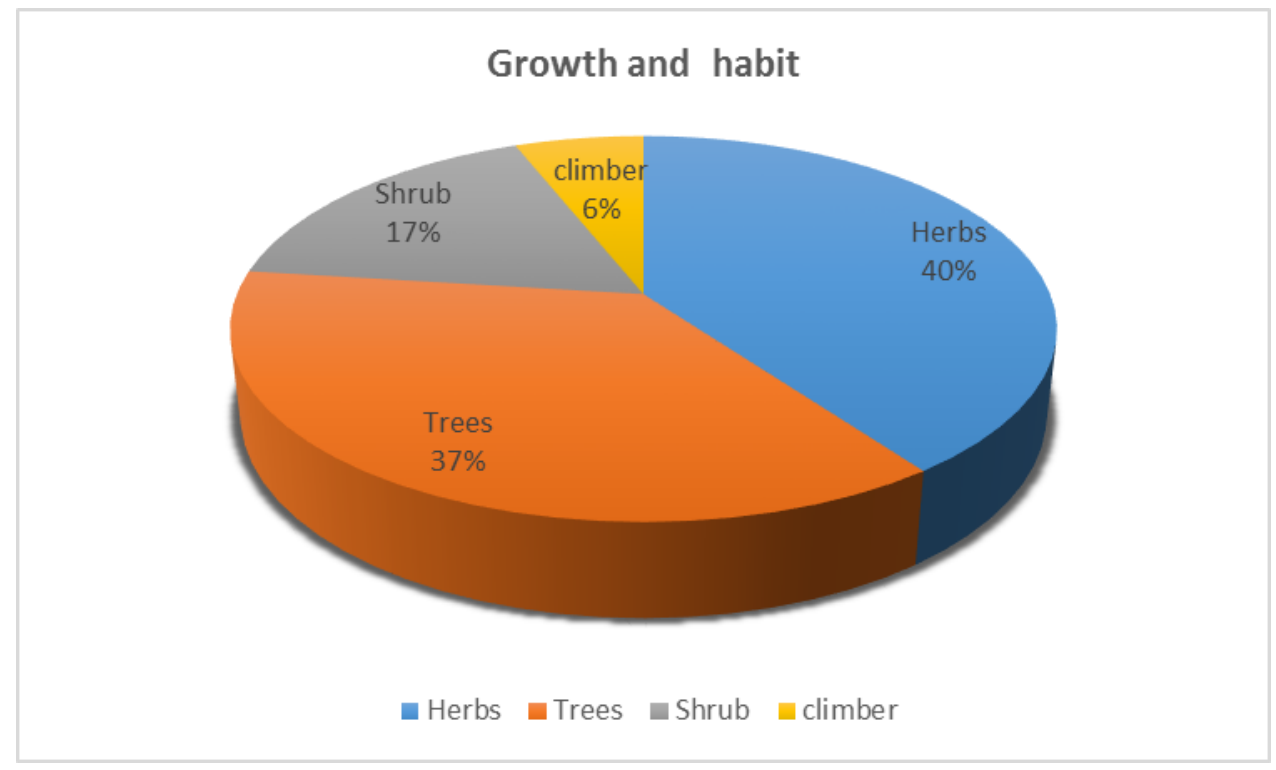

Figure 3. Growth and habit of plants in Maze national park

When compared with other national parks in Ethiopia such as Nechisar National Park and Omo National Park in species richness, the result is more or less similar in species composition. For example, Schloder (1999) in Omo National Park recorded 121 plant species among which grass species were 27. In Nechisar National Park 199 species belong to 44 families (Andargie, 2001) and 131 plant species representing 44 different 
families (Hasan, 2008). In all these studies the family Poaceae and Fabaceae were the dominant.

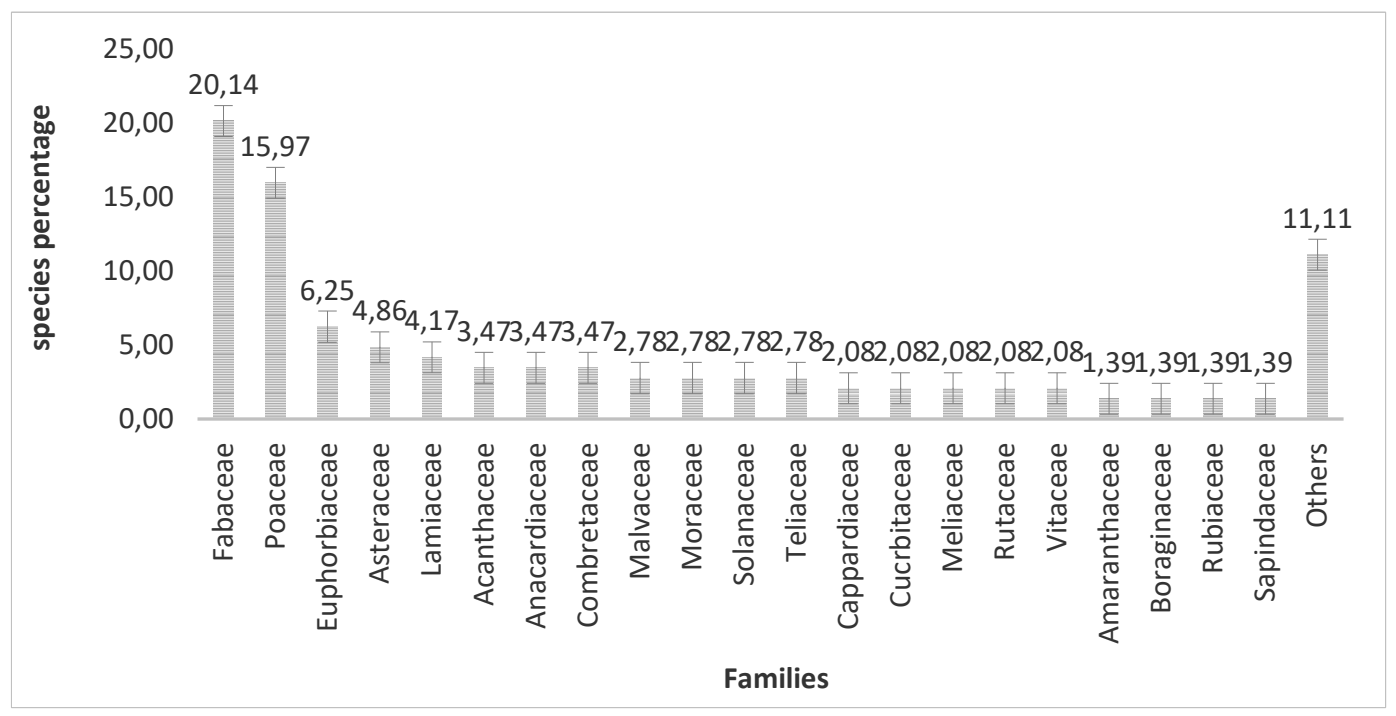

Figure 4. Families of plants with percentage of their species

The most diverse genus was Acacia represented by 8 species, Ficus and Panicum each represented by 4 species. Combretum, Hyparrhenia, Solanum, Grewia and Vernonia are the genera represented by 3 species while other genera were represented by one or two species as shown in the Figure 5 .

\section{Top 9 genera with number of species}

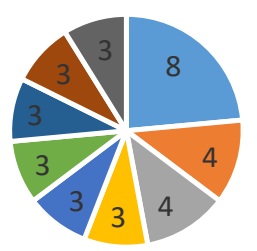

$$
\begin{aligned}
& \text { - Acacia } \quad \text { Ficus } \quad \text { Panicum } \| \text { Combretum }=\text { Grewia } \\
& \text { - Hyparrhenia " Indigofera | Solanium | Vernonia }
\end{aligned}
$$

Figure 5. Genera with the number of species

Vegetation is said to have high diversity if it has many species and their abundance is fairly even, conversely, diversity is low when the species are few and their abundance is unevenly distributed. In the present study, the highest species richness was found in community type IV, which is from the plain grassland with an open CombretumTerminalia woodland vegetation. An arrangement of the community types in decreasing order of species richness is IV, VI, V, II, I and III. The high species richness is probably 
attributed to the optimum environment that supports the Savanna Wooded land species or attributed to the minimum level of disturbances.

The community, which is relatively lower in species richness (community III), appears to have high evenness. An arrangement of the groups in decreasing evenness gives the order III, I, IV, VI, II, V. This arrangement does not agree with the arrangement of the community type in decreasing species richness. In some community type such as community type III, where the constituent species appear to be distributed evenly; there is less species richness as compared to others.

This study does not follow the diversity trends observed in species richness (Whittaker, 1975). It is highest in species rich and lowest in species poor community. Nevertheless, maximum diversity is achieved when each species is represented by equal numbers of individuals (Pielou, 1969). Therefore, from the present information at hand, maximum diversity could not be achieved, because communities with species rich in general did not appear to have an evenly distributed species. It is known that, the more number of species in an ecosystem and or community, the greater the stability. In other words, high environmental stability leads to higher community stability which in turn permits high diversity of species (Bormann and Kellert, 1991). Hence, community type II and V are considered to be in less stable environments and therefore have less species richness. Community type I and III also show lower species richness compared to the other community types, because they represent species from two and three sample plots respectively.

According to Kent and Coker (1992), The Shannon index is the most frequently used for the combination of species richness and relative abundance and the index normally varies between 1.5 and 3.5 and rarely exceeds 4.5 . In the present study, the index is between 2.11 and 2.66, showing more or less even representation of individuals of all species in the sampled quadrats. Since it is known that the increase in the number samples will increase the species encountered (McNaughton and Wolf, 1973), the less species richness encountered in community types I and III could be the few sample stands (plots) representing the community. Moreover, the area covered by these two (2) community types is also small, thus represented by few sample stands (plots). Riparian Plant Communities are rich in species and highly variable in species composition in both temperate and tropical systems (Pollock, 1998). However in this study the species richness is low in community VI which is from riparian vegetation and even the smallest species richness is recorded in plots which are under this community such as plot 50, 51 and 52 each with 6 species. The diversity of each cluster was calculated using Shannon diversity index based on cover abundance value of the species as input source. The Shannon Diversity computed for six different communities (Table 1) shows that community type $\mathrm{I}$ is the most diverse whereas community type $\mathrm{V}$ is the least diverse of plant species.

Table 1. Shannon Diversity Index of Species

\begin{tabular}{lllllll}
\cline { 2 - 7 } Diversity Index & \multicolumn{7}{c}{ Community } & type \\
\cline { 2 - 8 } & I & II & III & IV & V & VI \\
Species richness & 26 & 46 & 25 & 96 & 47 & 56 \\
Species diversity & 2.66 & 2.29 & 2.45 & 2.45 & 2.03 & 2.41 \\
Species evenness & 0.97 & 0.94 & 0.98 & 0.96 & 0.91 & 0.96 \\
\hline
\end{tabular}




\section{Plant communities}

The 65 plots studied were grouped into clusters with the aid of computer program TWINSPAN (Hill, 1979). Two-way TWINSPAN output resulted in a cluster of six plant community types at altitudes between $937 \mathrm{~m}$ and $1076 \mathrm{~m}$ a.s.l. including type I (Achyranthyus aspera- Combretum molle), type II (Rhus natalensis - A. drepanolobium), type III (Sorghum versicolor- Heteropogon contortus, type IV (Combretum adenogonum - Loudetia arundinacea), type V (A. polyacantha - A. senegal), type VI (A. polyacantha - Saccharum spontaneum) in Maze National Park.

The synoptic abundance cover value (Table 2) was used to clearly determine the dominant species in the community. The average cover/abundance value of each species in each cluster identified was computed and then characteristic species and local plant community types of the cluster were recognized. To know about the variation among plant communities ANOVA has been done using MINTAB 14 computer program (MINITAB, 1995). The following plant communities have been named by two dominant species based on the highest mean cover/abundance value that appears within a cluster (Table 2).

Table 2. Synoptic cover abundance values for species reaching $\geq 2 \%$ in at least one community

\begin{tabular}{|c|c|c|c|c|c|c|}
\hline Botanical Name & CI & CII & CIII & IV & $\mathbf{V}$ & VI \\
\hline Achyranthyes aspera & 32.5 & 7.86 & 0 & 0 & 2.6 & 3.2 \\
\hline Combretum molle & 27.5 & 0 & 0 & 4.6 & 0 & 0 \\
\hline Acacia seyal & 25 & 0 & 0 & 0 & 8.3 & 0 \\
\hline Rhynchosia minima var prostrata & 22.5 & 0 & 0 & 0 & 0 & 0 \\
\hline Asparagus flagellaris & 10 & 0 & 0 & 0 & 0 & 0 \\
\hline Ocimum urticifolia & 10 & 0 & 0 & 0 & 0 & 0 \\
\hline Harrisonia abyssinica & 7.5 & 0 & 10.3 & 0 & 0 & 0 \\
\hline Rhus natalensis & 7.5 & 31.57 & 6.7 & 2 & 5.1 & 0 \\
\hline Acacia drepanolobium. & 0 & 20.71 & 12 & 4.9 & 0 & 0 \\
\hline Acacia seyal & 0 & 20 & 0 & 0 & 4.4 & 0 \\
\hline Sorghum versicolor & 0 & 0 & 30 & 16.3 & 0 & 4.6 \\
\hline Heteropogon contortus & 0 & 0 & 15 & 8.2 & 0 & 0 \\
\hline Capparis tomentosa & 0 & 0 & 15 & 0 & 0 & 0 \\
\hline Grewia bicolor & 0 & 0 & 13.3 & 0 & 0 & 0 \\
\hline Euphorbia schimperiana & 0 & 0 & 13.3 & 0 & 0 & 0 \\
\hline Combretum adenogonium & 0 & 0 & 0 & 25.2 & 0 & 2.1 \\
\hline Loudetia arundinacea & 0 & 0 & 6.7 & 24.2 & 0 & 0 \\
\hline Acacia hockii & 0 & 0 & 0 & 4.3 & 0 & 0 \\
\hline Acacia senegal & 17.5 & 20.7 & 0 & 2.7 & 20 & 0 \\
\hline Panicum maximum & 0 & 5 & 0 & 4.1 & 18.3 & 19.8 \\
\hline Panicum porphyrrhizos & 0 & 17.1 & 0 & 13 & 16.4 & 2.8 \\
\hline Acacia polyacantha & 2.5 & 0 & 0 & 0 & 21.3 & 40.8 \\
\hline Ficus sycomorus & 0 & 0 & 0 & 0 & 5.8 & 15.8 \\
\hline Saccharum spontaneum & 0 & 0 & 0 & 0 & 0 & 31.5 \\
\hline
\end{tabular}




\section{The following plant communities were identified from the output of TWINSPAN}

\section{Type I. Achyranthyes aspera - Combretum molle community}

This community type is found between altitudinal ranges of 1024 and $1050 \mathrm{~m}$ a.s.1 and consists of 2 plots with 26 species. The dominating tree layer species in this community are Combretum molle, A. senegal, A. seyal, Bridelia scleroneura. Harrisonia abyssinica, Ocimum urticifolia, Lantana viburnoides, Asparagus flagellaris and Rhus natalensis are the shrub layer species in the community. The herb layer species belonging to this community are Achyranthes aspera, Justicia ladanoides and Sporobouls pyramidalis. This community is seen in the Tela Ayisera localities at the northern part of the park. This community is from disturbed area of the park and dominated by Achyranthes aspera.

\section{Type II. Rhus natalensis - Acacia drepanolobium community}

This community type is distributed between altitudinal ranges of $941 \mathrm{~m}$ and $1076 \mathrm{~m}$ a.s.l. and consists of 7 plots with 46 species. The dominant tree species are Acacia drepanolobium, A. seyal and A. senegal. Rhus natalensis and Clerodendrum myricoides are among the shrub and Panicum porphyrrhizos is the dominant grass in the community.

\section{Type III. Sorghum versicolor - Heteropogon contortus community}

This community consists of 3 plots and 25 species distributed between altitudinal ranges of $1010 \mathrm{~m}-1016 \mathrm{~m}$ a.s.l. The community is dominated by the cover abundance of grasses such as Sorghum versicolor, Heteropogon contortus and Hyparrhenia anthistirioides. Capparis tomentosa, Combretum aculeatum, Euphorbia schimperiana and Grewia bicolor are the common shrubs in the community while Acacia drepanolobium is the tree species found scattered in the community.

\section{Type IV. Combretum adenogonum - Loudetia arundinacea community}

This community consists of 3 plots and 25 species distributed between altitudinal ranges of $1010 \mathrm{~m}-1016 \mathrm{~m}$ a.s.l. The community is dominated by the cover abundance of grasses such as Sorghum versicolor, Heteropogon contortus and Hyparrhenia anthistirioides. Capparis tomentosa, Combretum aculeatum, Euphorbia schimperiana and Grewia bicolor are the common shrubs in the community while Acacia drepanolobium is the tree species found scattered in the community.

\section{Type V. Acacia polyacantha - Acacia senegal community}

This community type consists of 8 quadrats in which 46 species distributed between altitudinal ranges of $956 \mathrm{~m}$ and $1027 \mathrm{~m}$ a.s.l. This community consists of plots from riparian vegetation. In this community Acacia polyacantha and A. senegal are the most dominating tree layer species. A. albida, A. seyal, Ficus sycomorus, and Ziziphus spinachristi are the other common tree layer. Rhus natalensis and Panicum maximum are the dominant shrub and herb layer respectively. 


\section{Type VI. Acacia polyacantha - Saccharum spontaneum Community}

This community type consists of 13 quadrats with 56 species distributed between altitudinal ranges of $937 \mathrm{~m}$ and $1025 \mathrm{~m}$ a.s.1. This community also consists of plots from riparian vegetation and it is the second community in species richness next to community type IV. The most dominating tree species in this community are Acacia polyacantha, Ficus sycomorus, Lepidotrchilia volkensii, Terminalia brownii and Sclerocarya birrea, Setaria barbata, Saccharum spontaneum, Panicum maximum and Sorghum versicolor are the most dominating herb species

In order to know whether there is variation among the plant communities in species richness, evenness, diversity and altitude, one way ANOVA was done using MINTAB 14 computer program. The result of ANOVA showed that there was statistically significant difference among plant communities in species richness, altitude, evenness, and species diversity at $95 \%$ confidence interval (Table 3 ).

Table 3. Summary of ANOVA among the 6 communities

\begin{tabular}{lllllll}
\hline Source & DF & SS & MS & F & P & Remark \\
\hline $\begin{array}{l}\text { Species } \\
\text { richness }\end{array}$ & 5 & 180.16 & 36.03 & 3.61 & 0.006 & Significant \\
$\begin{array}{l}\text { Altitude } \\
\begin{array}{l}\text { Species } \\
\text { evenness }\end{array}\end{array}$ & 5 & 25868 & 5174 & 3.35 & 0.01 & Significant \\
$\begin{array}{l}\text { Species } \\
\text { diversity }\end{array}$ & 5 & 0.0235 & 0.0047 & 7.18 & 0 & Significant \\
\end{tabular}

A 2 sample t-test was done in order to know the existence of variation within a community using species richness, evenness, species diversity and altitude. The result of 2-sample t-test shows that there is a significant difference at a $95 \%$ confidence interval within community types (Table 4).

Table 4. Summary of t-test within 6 plant communities

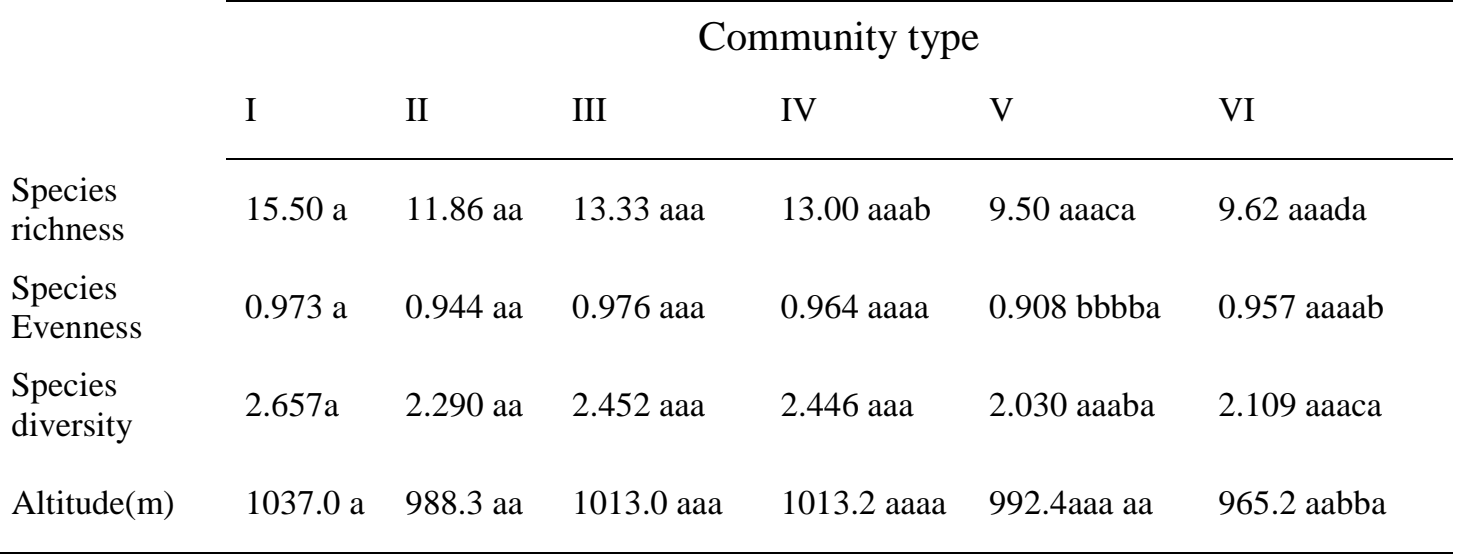

The comparison of plant communities based on the mean of species richness showed that plant community type IV, is significantly different from community type V and VI. 
Because community type IV is found on the upland plain while community type $\mathrm{V}$ and VI are found along riparian area. There is a similarity in species composition between community V and VI. This is due to their habitat that they are riparian vegetation along the Lemase and Maze rivers. In both community types Acacia polyacantha is the dominant species while Ficus sycomorus and Ehretia cymosa are commonly found. Plant communities also vary in their mean of species evenness. Community type $\mathrm{V}$ is significantly different from all other community types in species evenness. There is also a significant difference with in a community types in species diversity. Community type IV is significantly different from Community types V and VI. The reason for this is community type IV is found on the wooded grassland and wooded land part of the park while community type V and VI are from the riparian area. There is also significant variation in altitude with in the plant community types. Community type VI is significantly different from community type III and IV. The result of ANOVA showed that there is a significant difference among plant communities with respect to species diversity, richness, evenness and altitude at $\mathrm{P}<0.05$.

\section{Frequency}

Frequency denotes the number of plots in which a given species occurred in the study area. The four most frequently occurring tree species in Maze National Park are Combretum adenogonium 29 (44.6\%), Acacia polyacantha 26 (40.00\%), Grewia mollis $23(35.38 \%)$ and Maytenus senegalensis 22 (33.85\%), Acacia drepanolobium 20 (30.77), where as Panicum maximum 28 (43.08), Panicum porphyrrhizos 26 (40.00\%), Hyparrhenia filipendula 23 (35.38 \%), Loudetia arundinacea 23 (35.38 \%), and Sorghum versicolor $22(33.85 \%)$ are the frequently occurring grasses in the study area. Rhus natalensis $20(30.77 \%)$ is the shrub with highest frequency. Combretum adenogonium and Panicum maximum are widely found in the wooded grassland while Acacia polyacantha is found along riverine vegetation and swamp areas. The frequently occurrence of Combretum adenogonium in the woodland area may be due to fire resistant nature of the bark.

\section{Threats to the biodiversity of the area}

Ecosystems are being affected and destroyed by a wide variety of human activities which results in an irreversible loss of biodiversity. There are several threats that can cause reduction of biodiversity in Maze National Park, such as poaching, uncontrolled fire, and honey production (smoke), deforestation by the local communities which have been observed during the study time.

The armed groups of people around and inside the park have been causing problems on the park, and, hence it is very dangerous to enter the park. These illegal hunters and other people set fire to burn the vegetation in order to attract wild games for hunting, to make open foot tracks for better visibility, to avoid or protect themselves from dangerous harmful animals and to obtain young grass shoot for their livestock. Burning of the vegetation is commonly seen in almost all parts of the park during the dry season.

Seasonal burning is largely determined by the availability of ignition source and seasonal variation inflammability (Waring and Schlesinger, 1985). Besides seasonal burning in Maze National Park, the local people set fire deliberately during the dry season and just before the rainy season of the area to burn the vegetation in order to stimulate new and fresh leaves for grazing purpose. Burning of the vegetation results in 
altering the natural soil balance considerably by removing the humus from the surface of the topsoil, destroying microorganisms, and increasing the concentration of salts (Vickery, 1984). It also affects successions and disrupts the natural stability of the original climax community (Abrahmson, 1984). Fire can also leads to the extinction of unique community of plants and animals. On the other hand controlled fire management is necessary to the range lands of the park; to remove unpalatable grass, to avoid coarse forage and to initiate the microbial activity in the soil.

In the present study area, the cause of fire appears to be anthropogenic aiming at certain goals such as to attract wild games for hunting, to make open foot tracks for better visibility, to avoid or protect themselves from wild animals and to obtain new grass growth for their livestock. This may result in loss of biodiversity in the area in the future. Fire, clearing forest for construction, hunting for bush meat, overgrazing and over browsing by domestic stocks are the factors responsible for the change in vegetation composition of Maze National Park, while hunting is so dangerously affecting the wildlife fauna in the area, such conclusion is in line with Daubenmire (1974). Another threat to the biodiversity of the area is that the local community around the park cut trees inside the park for the purpose of building material and firewood (Figure 6) which results in deforestation of the area. Some of the wild animals in Maze National Park such as lion and leopard are feared by the local population and hence want to protect themselves by burning their habitat.

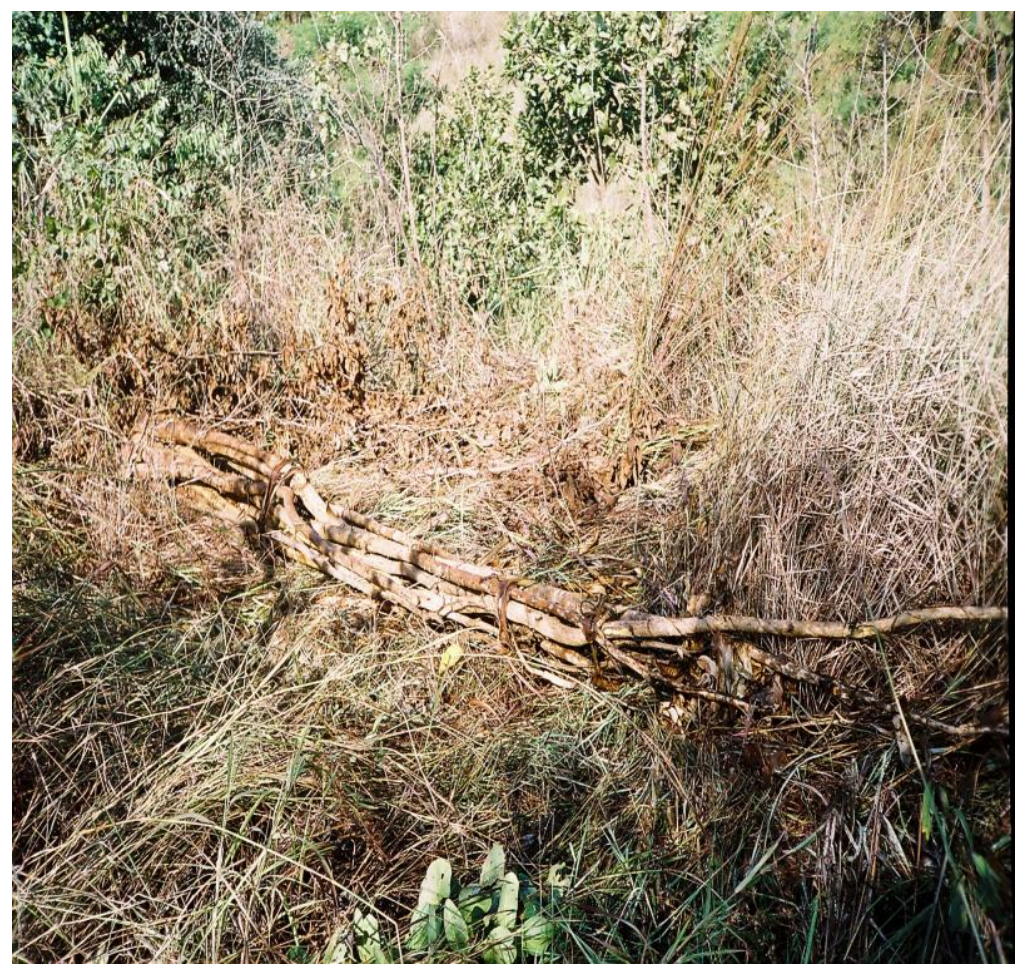

Figure 6. Title of the given figure, graph or image included in the document

In Ethiopia within 6 years a total of more than 148 fires covering an area of 100966 hectares has been reported (Table 5). The figure was noted in 2000 where forest areas of 95000 hectares have been burned. 
Table 5. Forest fire statistics of Ethiopia

\begin{tabular}{ccc}
\hline Year & $\begin{array}{c}\text { Total no. of fires } \\
\text { on forests and } \\
\text { other wooded } \\
\text { lands }\end{array}$ & $\begin{array}{c}\text { Area of } \\
\text { forest } \\
\text { burned (ha) }\end{array}$ \\
\hline 1990 & 4 & 1072 \\
1991 & 2 & 153 \\
1992 & 1 & 32 \\
1993 & 20 & 3159 \\
1994 & 1 & 1550 \\
2000 & $>120$ & 95000
\end{tabular}

\section{Conclusion and Recommendations}

Maze National Park is one of the national parks of Ethiopia with rich species' diversity representing the Combretum-Terminalia woodland vegetation. The study resulted in documentation of 144 vascular plant species representing 109 genera and 37 families. The five most species-diverse families tree layer in Maze National Park were Fabaceae/Leguminosae, Poaceae, Euphorbiaceae; Asteraceae and Lamiaceae. The most diverse genus was Acacia followed by Ficus and Panicum. Six plant communities were identified and described with varying degree of species richness, evenness and diversity. Plant community IV exhibited the highest species richness (96) while the highest diversity was observed for community type II. Community type III was known with the least species richness but highest species evenness. The result of ANOVA showed that there is statistically significant difference among plant communities in species richness, altitude, evenness, and species diversity at $95 \%$ confidence interval.

Anthropogenic activities in Maze National Park were identified to exert high pressure on the vegetation and wildlife in the area resulting in the loss of biodiversity underpinned by troubled natural habitat. The major anthropogenic activities in the study area with the aforementioned detrimental effects were: poaching, fire, cutting of trees for fuel wood purpose and construction. The most feasible recommendation to reverse the undesirable condition in the national park is to actively participate the local people in the conservation activities of the national park via ecotourism which is one form of sustainable tourism. For example landscape, wild animals, the hot springs and associated medicinal values, and many other cultural packages in the national park could be sustainably utilized for ecotourism in line with the sustainable development goals.

Since this study was limited to certain parts of the park, there is a need for more comprehensive studies in different parts of the park if proper and long-term management plan of the park is desired. In a nutshell, analysis of soil and other components of the natural environment should be some of the future research areas of the national park to enable sustainable management of the national park and other protected areas in Ethiopia.

Acknowledgements. The authors wish to express their sincere gratitude to the Ethiopian Wildlife Conservation Authority (EWCA) for funding for the research. The authors are very much grateful also to all organizations and persons for their full cooperation in providing necessary data and information in the whole research process. Our special thanks also go to anonymous reviewers. 


\section{REFERENCES}

[1] Abrahamson, N.G. (1984): Species response to fire on Florida Lake Wales Ridge. -American Journal of Botany 71: 35-45.

[2] Ahmet, Y.C, Meriç G. (2000): Marine Parks for protection and tourism. - Turkey Journal of Coastal Conservation 6: 57-60,

[3] Andargie, T. (2001): Floristic Composition and Ecology of the Savanna Grassland and Woodland. Vegetation in Nech Sar National Park and Its Conservation Status. Unpublished M. Sc Thesis, Addis Ababa University, Addis Ababa.

[4] Ayalew, A, Bekele, T and Demissew, S. (2006): The undifferentiated afromontane forest of Denkoro in the central highland of Ethiopia: a floristic and structural analysis. SINET: - Ethiopian Journal of Science. 29(1) :45-56.

[5] Bekele, T. (1994): Phytosociology and Ecology of a humid Afromontane forest on the central plateau of Ethiopia. - Journal of Vegetation Science. 5 (1): 87-98.

[6] BIDNTF (Biodiversity Indicators Development National Task Force) (2010): Ethiopia: Overview of Selected Biodiversity Indicators. Addis Ababa. pp. 48.

[7] Bormann, F.H and Kellert, S.R (ed). (1991): Ecology, Economics, Ethics. The Broken Circle. Yale University Press New Haven \& London.

[8] Chape, S, Blyth S, Fish L, Fox P, Spalding, M (2003): The 2003 United Nations List of Protected Areas, IUCN and UNEPWCMC, Cambridge, UK.

[9] Daubenmire, R.F. (1974): Plant and Environment. A text book of plant autecology: The fire factor. - John Willy and sons, Inc., New York.

[10] Debelo A.R. (2012): Contesting views on a protected area conservation and development in Ethiopia. Soc. Sci. 1: 24 - 46. doi:10.3390/socsci1010024

[11] Derje, T. (2003): Field Report on Maze Wild Life Reserve to SNNPRS Tourism, Park and Hotel Agency.

[12] Didita, M, Nemomissa, S, Gole, T.W. (2010): Floristic and structural analysis of the woodland vegetation around Dello Menna, Southeast Ethiopia. - Journal of Forestry research, 21(4) :395-408.

[13] Dudley, N. (Ed). (2008): Guidelines for Applying Protected Area Management Categories. Gland, Switzerland: IUCN. x + 86pp.

[14] ENMSA, Ethiopian National Meteorological Agency (2007): Climatic data collected at Morka Station, Gamo Gofa Zone, SNNPRS

[15] FDRESA, Federal Democratic Republic of Ethiopia Central Statistical Agency (2007): Statistical Abstract 38-39.

[16] FDRE, Federal Democratic Republic of Ethiopia (2007): Project Document United. Nations Development Program / Global Environment Facility: Sustainable Development of the Protected Area System of Ethiopia"

[17] Fennell, D.A. (2003): Ecotourism: An introduction. - Routledge, Taylor Francis Group: London and New York.

[18] Hasan, Y. (2008): Wood species encroachment and Ecological conditions in the grass plain of Nechisar National Park. M.Sc. Thesis (Unpublished), Addis Ababa, Ethiopia.

[19] Hill, M.O. (1979): TWINSPAN. AFORTRAN program for arranging multivariate data in an ordered two-way table classification of individuals and attributes. - Cornell University, Ithaca, NY.

[20] Holmberg, J. Ed. (1992): Making Development Sustainable: Redefining Institutions, Policy, and Economics, International Institute for Environment and Development, Island Press, Washington, DC.

[21] IBC, Institute of Biodiversity Conservation (2009) Convention on Biological Diversity Ethiopia's 4th Country Report. Addis Ababa, Ethiopia.

[22] IBC, Institute of Biodiversity Conservation (2012): Country Report Submitted to FAO on the State of Forest Genetic Resources of Ethiopia. 
[23] IUCN, International Union for Conservation of Nature (2004): The World Conservation Union. World Commission on Protected Areas. - Best Practice Protected Area Guidelines Series No. 11.

[24] Jayarman, K. (2000): A Statistical Manual for Forestry Research. - Bangkok: FORSPAFAO Publication.-

[25] Jha, P.K. (1997): Environment plant resources and quantities estimation methods for vegetation analysis. In: Shrestha, K.K., Jha, P.K., Shengi, P., Rastogi, A., Rajbandary, S., Joshi, M. (eds.). Ethnobotany for Conservation and Community Development. Ethnobotanical Society of Nepal (ESO), Nepal

[26] Katherine, M. M (2013): Community Perceptions of Forests, Conservation and Livelihoods in La Tigra National Park, Honduras .Thesis unpublished. Calgary, Alberta

[27] Kelbessa, E, Demissew, S. (2014): Diversity of Vascular Plant Taxa of the Flora of Ethiopia and Eritrea Ethiop. - J. Biol. Sci. Vol. 13 (Supp.): 37-45,

[28] Kelboro, G, Stellmacher, T. (2012): Contesting the National Park theorem? Governance and land use in Nech Sar National Park, Ethiopia. Working Paper 104.

[29] Kent, M, Coker, P. (1992): Vegetation Description and Analysis: A Practical Approach. Belhaven Press, London 363 pp.

[30] Khadka, D, Nepal, S.K. (2010): Local responses to participatory conservation in Annapurna Conservation Area, Nepal. - Environmental Management 45(2): 351-362. DOI 10.1007/s00267-009-9405-6

[31] Lovett, J.C, Rudd, S, Taplin, J, Frimodt-Møller, C. (2000): Patterns of plant diversity in Africa south of the Sahara and their implications for conservation management. Biodiversity \& Conservation 9(1) :37-46.

[32] Martin, G.J. (1995): Ethnobotany: A Methods Manual. Chapman and Hall, London, 267 pp.

[33] McNaughton, S.J, and Wolf, L.L (1973): General Ecology. - Holt, Rinehart and Winston, Inc. New York

[34] MINITAB (1995), MINITAB for Windows release 10.51Xtra. IBG Uppsala University. Minitab Inc.

[35] Minster of Agriculture (2000): Proceedings of the Ethiopian Round Table Workshop on Forest Fire Management (in Press). Addis Ababa.

[36] Muhumuza, M, Balkwill, K. (2013): Factors Affecting the Success of Conserving Biodiversity in National Parks: A Review of Case Studies from Africa. - International Journal of Biodiversity. http://dx.doi.org/10.1155/2013/798101

[37] Muller-Dombois, D, Ellenberg, D.H (1974): Aims and Methods of vegetation ecology. John Willy and sons, Inc., New York.

[38] Naveh, Z, Whittaker, R.H. (1980): Structural and floristic diversity of shrub lands and woodlands in northern Israel and other Mediterranean areas. - Vegetatio 41(3):171-190

[39] Noss, R.F. (1999): Assessing and monitoring forest biodiversity: A suggested framework and indicators. - Forest Ecology and Management 115:135-146

[40] Pielou, E.C (1969): An introduction to Mathematical Ecology. John Wiley and Sons, Inc. New York.

[41] Pollock, M.M. (1998). Plant species richness in riparian wetlands-a test of biodiversity theory. - Ecology 79: 94-105.

[42] Rai, S.C, Sundriyal RC (1997): Tourism and biodiversity conservation: the Sikkim Himalaya. - Ambio, 26: 235-242.

[43] Refera, B, Bekele, A. (2006): Population status and structure of Swayne's Hartebeest (Alcelaphus buselaphus swaynei) in Mazie National Park, Ethiopia. - Int. J. Ecol. Environ. Sci.32:259-264.

[44] Schloder, C.A. (1999): Investigation of the determinants of African Savana vegetation distribution: A case study from the Lower Omo Basin, Ethiopia (Dissertation). - Utah State University. Logan, Utha 
[45] Senbeta, F, Teketay, D. (2003): Diversity, community types and population structure of woody plants in Kimphee Forest, a virgin nature reserve in southern Ethiopia. - Ethiopian Journal of Biological Sciences. 2(2). 169-187.

[46] Demissew, S. (1980): A study on the structure of a montane forest. The Managesha State Forest. M.Sc. Thesis, (Unpublished), Addis Ababa, Ethiopia.

[47] Shackelton, C.M. (2000): Comparison of Plant Diversity in Protected and Communal Lands in Bushbuck ridge Lower Savana, South Africa. - Biological Conservation 94: 273-285.

[48] Shannon,C.E, Wiener, W .(1949). The Mathematical Theory of Communication. University ofllinois, Chicago, USA.

[49] Chanie, S, Tesfaye, D. (2015): Threats of biodiversity conservation and ecotourism activities in Nechisar National Park, Ethiopia. - International Journal of Biodiversity and Conservation Vol. 7(2):130-139. DOI: 10.5897/IJBC2014.0752.

[50] Stellmacher, T. (2007): The historical development of local forest governance in Ethiopia. Africa Spectrum. - German Institute of Global and Area Studies. 3: 519 - 531

[51] Stellmacher, T, Nolten, R. (2010): Forest resource use and local decision making in the Bale Mountains coffee forests, Ethiopia. - In: I. Eguavoen, W. Laube (eds.) Negotiating local governance. natural resources management at the interface of communities and the state. Lit Publishing, Berlin.

[52] Siraj, M., Zhang, K., Xiao, W., Bilal, A., Gemechu, S., Geda, K., \& Xiaodan, L. (2016). Does Participatory Forest Management Save the Remnant Forest in Ethiopia?. Proceedings of the National Academy of Sciences, India Section B: Biological Sciences, 1-14.

[53] Tekalign, W, Bekele, A. (2011): Current Population Status of the Endangered Endemic Subspecies of Swayne's Hartebeest (Alcelaphus buselaphus swaynei) in Maze National Park, Ethiopia. SINET: - Ethiopian Journal of Science, 34(1): 39-48.

[54] Tothill, J.C. (1978): Measuring botanical composition of grassland. - In: The Mantetje. L. (Ed.) Measuring grassland vegetation and animal production. Common wealth Agriculture bureeaux.22-52.

[55] UNDP, United Nations Development Program (1994): Human Development Report.

[56] Van der Maarel, E. (1979): Transformation of cover/abundance value in Phytosociology and its effect on community similarity. - Vegetatio 39: 97-114.

[57] Vickery, L.M. (1984): Ecology of Tropical Plants. - John Wiley and Sons Ltd., Great Britain.

[58] Vreugdenhil, D, Vreugdenhil, A.D, Tamirat, T, Anteneh, Sh, Zelealem, T. (2012) : Gap Analysis of the Ethiopia Protected Areas System, Executive Summary, with technical contributions from Nagelkerke L, Gedeon K, Spawls S, Yalden D, Lakew Berhanu, and Siege, L World Institute for Conservation and Environment, USA

[59] Waring, H.R. and Schlesinger, H.W. (1985): Forest Ecosystem Concept and Management. - Academic Press. Inc. London.

[60] WBISPP, Woody Biomass Inventory and Strategic Planning Project (1995): Towards a Strategic Plan for the Sustainable Development and Conservation of the Woody Biomass Resources, Addis Ababa.

[61] Whittaker, R. H .(1975): Communities and Ecosystems. 2nd ed. - Macmillan publishing Co., Inc., New York

[62] Woldu, Z. (1999): Forest in the vegetation type of Ethiopia and their status in the geographical context. - In: Forest Genetic Resources Conservation: Principles, Strategies and Action. Proceedings of the National Forest Conservation Strategy Development Work-shop, June 21-22, Addis Ababa, Ethiopia, pp. 1-36. 